\title{
FAKTOR-FAKTOR YANG BERHUBUNGAN DENGAN PENYAKIT REMATIK PADA LANSIA DI DESA TIAL KECAMATAN SALAHUTU KABUPATEN MALUKU TENGAH
}

\author{
Tommy Pangandaheng, ${ }^{*}$,Frans Wenno, Nurvita Sara Rolobessy \\ Akademi Keperawatan Rumkit Tk. III. dr. J. A. Latumeten Ambon \\ *e-mail: tomspup1907@gmail.com*
}

\begin{abstract}
Rheumatism is a disease that attacks the joints and bones or supporting tissues around the joints. This disease class is an autoimmune disease that affects many elderly people aged 50 years and over. Based on the prevalence of arthritis pain in Indonesia alone, it reaches $23.3 \%-31.6 \%$ of the total population of Indonesia. This figure shows that pain due to rheumatism has greatly disturbed the activities of Indonesian society. The research objective was to determine the factors associated with rheumatic disease in the elderly in Tial Village, Salahutu District, Central Maluku Regency. The research design used in this study is a type of analytical research with a cross-sectional study approach. The number of population studied in this study was 69 people, so the researchers made all populations into the research sample (total sampling). The statistical test used in this study is the Fhiser's test. Based on the value of Fisher's test, the p value is obtained: 0.000 which means less than $\alpha$. Thus it can be said that there is a significant relationship between work and rheumatic disease in the elderly in Tial Village and that there is a significant relationship between types of food and rheumatic disease in the elderly in Tial Village.
\end{abstract}

Keywords: Rheumatism, factor analysis, elderly

\begin{abstract}
ABSTRAK
Rematik adalah penyakit yang menyerang sendi dan tulang atau jaringan penunjang sekitar sendi, golongan penyakit ini merupakan penyakit autoimun yang banyak diderita oleh kaum lanjut usia 50 tahun ke atas. Berdasarkan prevalensi nyeri arthritis di Indonesia sendiri mencapai 23,3\% - 31,6\% dari jumlah penduduk Indonesia angka ini menunjukan bahwa nyeri akibat rematik sudah sangat mengganggu aktivitas masyarakat indonesia. Tujuan penelitian adalah untuk mengetahui faktor-faktor yang berhubungan dengan penyakit rematik pada lansia di Desa Tial Kecamatan Salahutu Kabupaten Maluku Tengah. desain penelitian yang digunakan dalam penelitian ini adalah jenis penelitian analitik dengan pendekatan Cross-Sectional Study. Jumlah populasi yang diteliti pada penelitian ini 69 orang, maka peneliti menjadikan semua populasi menjadi sampel penelitian (total sampling). Uji statistik yang digunakan pada penelitian ini adalah uji Fhiser's. Berdasarkan nilai hasil uji Fisher's diperoleh nilai $p$ : 0,000 yang berarti kurang dari $\alpha$. Dengan demikian dapat dikatakan bahwa ada hubungan yang bermakna antara pekerjaan dengan penyakit rematik pada lansia di Desa Tial dan bahwa ada hubungan yang bermakna antara jenis makanan dengan penyakit rematik pada lansia di Desa Tial.
\end{abstract}

Kata kunci: Rematik, analisis faktor, lansia

\section{PENDAHULUAN}

Keberhasilan Pemerintah dalam Pembangunan Nasional, telah mewujudkan hasil yang positif diberbagai bidang, yaitu adanya kemajuan ekonomi, perbaikan lingkungan hidup, kemajuan ilmu pengetahuan dan teknologi, terutama di bidang kesehatan, sehingga dapat meningkatkan kualitas kesehatan penduduk serta meningkatkan umur harapan hidup manusia. Akibatnya jumlah penduduk yang berusia lanjut meningkat dan bertambah cenderung lebih cepat (Setiabudhi, 2005).

Sejalan dengan semakin meningkatnya usia seseorang, maka akan terjadi perubahan-perubahan pada tubuh manusia. Perubahan-perubahan tersebut terjadi sejak awal kehidupan hingga usia lanjut pada semua organ dan jaringan tubuh. Keadaan demikian itu tampak pula pada semua sistem muskuloskeletal dan jaringan yang lain yang ada kaitannya dengan kemungkinan timbulnya beberapa golongan rematik (Stanley, 2006).

Rematik adalah penyakit yang menyerang sendi dan tulang atau jaringan penunjang sekitar sendi, golongan penyakit ini merupakan penyakit autoimun yang banyak diderita oleh kaum lanjut usia 50 tahun ke atas (Junaidi, 2006).

Menurut Organisasi Kesehatan Dunia WHO tahun 2011 rematik merupakan penyakit degeneratif yang timbul pada usia lanjut penyakit ini biasanya terjadi pada laki-laki maupun perempuan. Diperkirakan penderita rematik di dunia telah mencapai 335 juta jiwa, artinya 1 dari 6 orang 
penduduk bumi ini menderita rematik, angka ini terus meningkat dan pada tahun 2025 di perkirakan $25 \%$ dari penduduk dunia akan mengalami kelumpuhan akibat kerusakan tulang dan penyakit sendi.

Di Amerika sekitar 37 juta penduduk yang menderita arthritis. Dalam berbentuk jumlah ini berarti 1 dari 7 orang amerika menderita arthritis. pada kelompok umur $>55$ tahun penderita gangguan sendi lebih banyak pada perempuan dan kebanyakan sakit sendi bentuk osteoarthritis (Smart, 2010).

Berdasarkan prevalensi nyeri arthritis di Indonesia sendiri mencapai 23,3\% - 31,6\% dari jumlah penduduk Indonesia angka ini menunjukan bahwa nyeri akibat rematik sudah sangat mengganggu aktivitas masyarakat indonesia (Zeng Q.Y, 2010).

Banyak penyakit yang terjadi pada lansia yang dipengaruhi oleh proses penuaan, usia, status pekerjaan, makanan dan aktivitas fisik adalah penyakit hipertensi, diabetes melitus, kardiovaskuler dan penyakit rematik. Salah satu penyakit yang berhubungan dengan nyeri pada persendiaan dan tulang yang biasa dikeluhkan lansia akibat nyeri yang dirasakan sangat mengganggu aktifitas adalah penyakit reumatik (Smart, 2010).

Nyeri yang dirasakan akibat rematik sangat mengganggu dalam kehidupan lansia sehingga susah dalam melakukan aktifitas, disamping itu masih banyaknya pandangan masyarakat Indonesia yang menggap remeh penyakit ini karena sifatnya yang seakan tidak menimbulkan ancaman jiwa, padahal rasa nyeri yang ditimbulkan akibat penyakit ini justru menjadi penghambat yang sangat mengganggu bagi masyarakat untuk melakukan aktivitas mereka seharihari (Handono, 2009).

Data dari Departemen Kesehatan Provinsi Ambon penyakit terbanyak di puskesmas yaitu ispa, malaria, TB, hipertensi, gastritis, diare, cacingan, arthritis, serta scabies. Sedangkan penyakit utama Rawat inap di Rumah Sakit Provinsi Maluku tahun 2008 khususnya penyakit rematik berada pada urutan ke 5 dari 9 jenis penyakit (Dinkes Maluku, 2009).

Sesuai dengan data dari Puskesmas Perawatan Suli khususnya Desa Tial Kecamatan Salahutu Kabupaten Maluku Tengah menunjukan bahwa jumlah lansia yang datang memeriksakan diri ke Puskesmaspada tahun 2010 yaitu sebanyak 74 orang, tahun 2011 yaitu sebanyak 72 orang, tahun 2012 yaitu sebanyak 79 orang, tahun 2013 yaitu sebanyak 69 orang (data bulan januari-oktober).

Berdasarkan data awal diatas menunjukan adanya peningkatan jumlah penduduk yang datang memeriksakan diri ke puskesmas dengan gejala rematik. Dalam studi pendahuluan yang peneliti lakukan kepada 5 orang lansia di desa tial di dapatkan data bahwa 3 orang di antaranya sering mengalami nyeri dan bengkak, lansia mengatakan susah dalam melakukan aktifitas seperti jalan kaki, mandi bahkan bangun dari tempat tidur sangat susah akibat dari nyeri persendian. Berdasarkan data-data tersebut peneliti tertarik untuk meneliti mengenai Faktorfaktor Yang Berhubungan Dengan Penyakit Rematik Pada Lansia di Desa Tial Kecamatan Salahutu Kabupaten Maluku Tengah.

\section{METODE}

Berdasarkan tujuan penelitian maka desain penelitian yang digunakan dalam penelitian ini adalah jenis penelitian analitik dengan pendekatan CrossSectional Study. Penelitian Cross-Sectional adalah jenis penelitian yang menekankan pada waktu pengukurann observasi data variabel independen dan dependen hanya satu kali, pada satu saat (Notoatmodjo, 2012). Dimana penelitian ini bertujuan untuk menganalisis faktor-faktor yang berhubungan dengan penyakit rematik pada lansia.

Sampel adalah sebagian yang diambil dari keseluruhan objek yang diteliti dan dianggap mewakili seluruh populasi (Notoatmodjo, 2012). Oleh karena jumlah populasi yang diteliti pada penelitian ini 69 orang, maka peneliti menjadikan semua populasi menjadi sampel penelitian (total sampling).

Uji statistik yang digunakan pada penelitian ini adalah uji Chi-Square jika memenuhi syarat, tetapi tidak memenuhi syarat digunakan uji Fhiser's.Untuk melihat hasil kemaknaan perhitungan statistik digunkan batas kemaknaan $\alpha=(0,05)$ hasil uji statistik dikatakan bermakna apabila mempunyai nilai dengan tingkat kemaknaan $\mathrm{p}<0,05$ dan tidak bermakna apabila mempunyai $\mathrm{p}>0,05$.

Dalam melakukan penelitian, peneliti memandang perlu adanya rekomondasi dari pihak institusi atas pihak lain dengan mengajukan permohonan izin kepada instansi tempat penelitian dalam hal ini Puskesmas Perawatan Suli dan Kepala desa Tial Kecamatan Salahutu Kabupaten Maluku Tengah.

\section{HASIL \\ Analisa Univariat \\ Jenis Kelamin}

Tabel 1

Distribusi Responden Berdasarkan Jenis Kelamin

\begin{tabular}{ccc}
\hline Jenis Kelamin & Frekuensi & $\begin{array}{c}\text { Persentase } \\
(\%)\end{array}$ \\
\hline Laki-laki & 25 & 36,2 \\
Perempuan & 44 & 63,8 \\
\hline Total & 69 & 100,0 \\
\hline
\end{tabular}

Sumber : Data Primer, 2019. 
Dari tabel 1 di atas menunjukan bahwa sebagian besar responden berjenis kelamin perempuan yaitu berjumlah 44 orang $(63,8 \%)$, sedangkan sebagian kecil berjenis kelamin laki-laki yaitu 25 orang $(36,2 \%)$

\section{Pekerjaan}

Tabel 2

Distribusi Responden Berdasarkan Pekerjaan Pada Lansia Di Desa Tial

\begin{tabular}{ccc}
\hline Pekerjaan & Frekuensi & Persentase $(\%)$ \\
\hline Tidak bekerja & 19 & 27,5 \\
Bekerja & 50 & 72,5 \\
\hline Total & 69 & 100,0 \\
\hline
\end{tabular}

Sumber Data : Primer, 2019.

Dari tabel 5.4 di atas menunjukan bahwa sebagian besar responden masih bekerja yaitu berjumlah 50 orang $(72,5 \%)$, sedangkan sebagian kecil tidak bekerja berjumlah 19 orang $(27,5 \%)$.

\section{Jenis Makanan}

Tabel 3

Distribusi Responden Berdasarkan Jenis Makanan Pada Lansia Di Desa Tial

\begin{tabular}{ccc}
\hline Pekerjaan & Frekuensi & Persentase $(\%)$ \\
\hline Tidak Beresiko & 11 & 15,9 \\
Beresiko & 58 & 84,1 \\
\hline Total & 69 & 100,0 \\
\hline
\end{tabular}

Sumber Data : Primer, 2019.

Dari tabel 3 di atas menunjukan bahwa sebagian besar jenis makanan beresiko dengan jumlah 58 orang $(84,1 \%)$, sedangkan sebagian kecil tidak beresiko berjumlah 11 orang $(15,9 \%)$.

\section{Penyakit Rematik}

Tabel 4

Distribusi Responden Berdasarkan Penyakit Rematik Pada Lansia Di Desa Tial

\begin{tabular}{ccc}
\hline Penyakit Rematik & Frekuensi & Persentase $(\%)$ \\
\hline Tidak Menderita & 8 & 11,6 \\
Menderita & 61 & 88,4 \\
\hline Total & 69 & 100,0
\end{tabular}

Sumber Data : Primer, 2019.

Dari tabel 4 di atas menunjukan bahwa sebagian besar responden yang berkunjung memeriksakan diri ke puskesmas dari 69 orang yang terdiagnosa medis menderita penyakit rematik berjumlah 61 orang $(88,4 \%)$, sedangkan yang tidak menderita rematikberjumlah 8 orang $(11,6 \%)$.

\section{Analisa Bivariat \\ Jenis Kelamin Dengan Penyakit Rematik}

Tabel 5

Distribusi Responden Berdasarkan Jenis Kelamin

Pada Lansia Dengan Penyakit Rematik Di Desa Tial

\begin{tabular}{ccccc}
\hline \multirow{2}{*}{ Jenis } & \multicolumn{2}{c}{ Penyakit Rematik } & Total & Nilaip \\
\cline { 2 - 4 } Kelamin & $\begin{array}{c}\text { Tidak } \\
\text { Menderita }\end{array}$ & Menderita & & \\
\hline Laki-laki & 6 & 19 & 25 & \\
& $(24,0 \%)$ & $(76,0 \%)$ & $(100 \%)$ & \\
Perempuan & 2 & 42 & 44 & \multirow{2}{*}{0,023} \\
& $(4,5 \%)$ & $(95,5 \%)$ & $(100 \%)$ & \\
\hline Total & 8 & 61 & 69 & \\
& $(11,6 \%)$ & $(88,4 \%)$ & $(100 \%)$ & \\
\hline
\end{tabular}

Sumber Data : Primer, 2019.

Dari tabel 5 menunjukan bahwa responden yangjenis kelaminlaki-laki dengan yangtidak menderitapenyakit rematik sebanyak 6 orang $(24,0 \%)$, dan responden yang menderita penyakit rematik berjumlah 19 orang $(76,0 \%)$. Sedangkan responden yang jenis kelamin perempuan dengan yang tidak menderita penyakit rematik berjumlah 2 orang $(4,5 \%)$, danrespondenyang menderita penyakit rematik sebanyak 42 orang $(95,5 \%)$. Sesuai dengan uji statistik menggunakan Fisher's diperoleh nilai $p$ 0,023 sehingga dikatakan nilai $p<0,05$, maka Ha di terima dan Ho di tolak.

\section{Pekerjaan dengan Penyakit Rematik}

Tabel 6

Distribusi Responden Berdasarkan Pekerjaan Pada Lansia Dengan Penyakit Rematik Di Desa Tial

\begin{tabular}{ccccc}
\hline \multirow{2}{*}{ Pekerjaan } & \multicolumn{2}{c}{ Penyakit Rematik } & & \multirow{2}{*}{ Nilai } \\
\cline { 2 - 3 } & $\begin{array}{c}\text { Tidak } \\
\text { Menderita }\end{array}$ & Menderita & Total & $p$ \\
\hline Tidak & 7 & 12 & 19 & \\
Bekerja & $(36,8 \%)$ & $(63,2 \%)$ & $(100,0 \%)$ & \\
& 1 & 49 & 50 & \multirow{2}{*}{0,000} \\
Bekerja & $(5,8 \%)$ & $(44,2 \%)$ & $(100,0 \%)$ & \\
\cline { 1 - 4 } Total & 8 & 61 & 69 & \\
& $(11,6 \%)$ & $(88,4 \%)$ & $(100,0 \%)$ & \\
\hline
\end{tabular}

Sumber Data : Primer, 2019.

Dari tabel 6 menunjukan bahwa responden yangtidak bekerja dengan yang tidak menderita penyakit rematik sebanyak 7 orang(36,8\%), dan responden yang menderita penyakit rematik berjumlah 12 orang $(63,2 \%)$. Sedangkan responden yang bekerja dengan yangtidak menderita penyakit rematikberjumlah 1 orang $(5,8 \%)$, danresponden yangmenderita sebanyak 49 orang $(44,2 \%)$. Sesuai dengan uji statistik menggunakan Fisher's diperoleh nilai $p 0,000$ sehingga dikatakan nilai $p<0,05$, maka Ha di terima dan Ho ditolak. 


\section{Jenis Makanan Dengan Penyakit Rematik}

Tabel 7

Distribusi Responden Berdasarkan Jenis Makanan Pada Lansia Dengan Penyakit Rematik di Desa Tial

\begin{tabular}{lllll}
\hline \multirow{2}{*}{$\begin{array}{l}\text { Jenis } \\
\text { Makanan }\end{array}$} & \multicolumn{2}{l}{ Penyakit Rematik } & & Nilai \\
\cline { 2 - 3 } & $\begin{array}{l}\text { Tidak } \\
\text { Menderita }\end{array}$ & Menderita & & $p$ \\
\hline Tidak & 8 & 3 & 11 & \\
Beresiko & $(72,7 \%)$ & $(27,3 \%)$ & $(100 \%)$ & \\
& 0 & 58 & 58 & \multirow{2}{*}{0,000} \\
Beresiko & $(, 0 \%)$ & $(100,0 \%)$ & $(100 \%)$ & \\
\hline Total & 8 & 61 & 69 & \\
& $(11,6 \%)$ & $(88,4 \%)$ & $(100 \%)$ & \\
\hline
\end{tabular}

Sumber Data : Primer, 2019.

Dari tabel 7 menunjukan bahwajenis makanan yang tidak beresiko dengan yang tidak menderitapenyakit rematik berjumlah 8 orang $(72,7 \%)$, danyang menderita penyakit rematik berjumlah 3 orang $(27,3 \%)$. Sedangkan jenis makanan yang beresiko dengan yang tidak menderita penyakit rematik tidak ada $(0 \%)$, danyang menderita penyakit rematik sebanyak 58 orang $(100,0 \%)$. Sesuai dengan uji statistik menggunakan Fisher's diperoleh nilai p0,000 sehingga dikatakan nilai $p<0,05$, maka Ha diterima dan Ho ditolak.

\section{PEMBAHASAN}

\section{Variabel Jenis Kelamin Dengan Penyakit Rematik} Pada Lansia Di Desa Tial

Dari hasil penelitian menunjukan bahwa responden yang berjenis kelamin laki-laki dengan penyakit rematik yang tidak menderita sebanyak 6 orang, sedangkan responden yangberjenis kelamin laki-laki dengan penyakit rematik yang responden sedang menderita berjumlah 19 orang. Sedangkan jenis kelamin perempuan dengan penyakit rematik yang tidak menderita berjumlah 2 orang, sedangkan jenis kelamin perempuan dengan penyakit rematik tetapi menderita sebanyak 42 orang. Sesuai dengan uji statistik menggunakan Fisher's diperoleh nilai $p 0,023$ sehingga dikatakan nilai $p<0,05$, maka Ha di terima dan Ho di tolak.

Menurut Hembing, W. (2006). Wanita lebih sering terkena osteoartritis lutut dan sendi, dan lelaki lebih sering terkena osteoartritis paha, pergelangan tangan dan leher. Secara keseluruhan dibawah 45 tahun frekuensi osteoartritis kurang lebih sama pada laki dan wanita tetapi diatas 50 tahun frekuensi osteoartritis lebih banyak pada wanita dari pada pria hal ini menunjukkan adanya peran hormonal pada patogenesis osteoartritis.

Dalam melakukan penelitian, peneliti mendapatkan sebagian responden yang berjenis kelamin laki-laki, yang menderita rematik 16 orang dan yang tidak menderita 6 orang, sedangkan yang berjenis kelamin perempuan yang menderita rematik sebanyak 42 orang, dan yang tidak menderita hanya 2 orang hal ini dilihat dari kuesioner yang dibagikan kepada responden yang berjumlah 69 orang.

Berdasarkan hasil penelitian di atas peneliti berasumsi bahwa kenapa wanita lebih cenderung menderita rematik dibandingkan laki-laki sesuai dengan teori yang sudah ada dan sesuai dengan faktafakta yang sudah dilakukan peneliti-peneliti terdahulu ini diakibatkan salah satu faktor yang sangat beperan penting yaitu hormon dalam tubuh.

\section{Variabel Pekerjaan Dengan Penyakit Rematik Pada Lansia Di Desa Tial}

Dari hasil penelitian menunjukan bahwa responden yangtidak bekerja dengan yang tidak menderita rematik sebanyak 7 orang sedangkan responden dengan tidak bekerja tetapi menderita rematik berjumlah 12 orang. Sedangkan responden yang bekerja yang tidak menderita rematik berjumlah 1 orang, sedangkan responden yang bekerja tetapi menderita rematik sebanyak 49 orang. Sesuai dengan uji statistik menggunakan Fisher's diperoleh nilai $p 0,000$ sehingga dikatakan nilai $p<0,05$, maka Ha di terima dan Ho di tolak.

Menurut Smart (2010), sikap badan yang salah dalam melakukan pekerjaan sehari-hari memudahkan timbulnya reumatik nonartikuler. Mengangkat beban berat dari lantai dengan badan membungkuk dapat mengakibatkan sakit pinggang. Pada petani yang sering berkebun dan memikul benda - benda yang berat, pemain tenis, karena seringnya melakukan pukulan back hand yang keras atau cedera lain, dapat menimbulkan rasa nyeri dan peradangan pada jaringan otot siku lengan yang disebut dengan tennis elbow.

Berdasarkan hasil penelitian, peneliti mendapatkan sebagian responden yang tidak bekerja, yang tidak menderita rematik 6 orang dan yang menderita 6 orang, sedangkan yang bekerja yang menderita rematik sebanyak 49 orang, dan yang tidak menderita hanya 1 orang hal ini dilihat dari kuesioner yang dibagikan kepada responden yang berjumlah 69 orang. Disamping itu juga peneliti mendapatkan data bahwa tempat penelitian yang dilakukan dengan jumlah responden hampir keseluruhan responden masih dapat menghasilkan uang untuk memenuhi kebutuhan ekonomi sehari-hari mereka masih bekerja, kebanyakan pekerjaan mereka yaitu petani, buruh, swasta, PNS.

Peneliti berasumsi bahwa hal ini dikarenakan akibat pekerjaan yang aktivitasnya berlebihan dengan umur yang sudah lansia dapat menimbulkan penyakit rematik dan memperberat penyakit tersebut. 


\section{Jenis Makanan Dengan Penyakit Rematik Pada Lansia}

Dari hasil penelitian menunjukan bahwa jenis makanan yang tidak beresiko dengan responden yang tidak menderita rematik berjumlah 8 orang, sedangkan jenis makanan yang tidak beresiko tetapi responden menderita rematik berjumlah 3 orang. Sedangkan jenis makanan yang beresiko dengan responden yang tidak menderitarematik tidak ada, sedangkan beresiko dengan penyakit rematik tetapi menderita sebanyak 58 orang. Sesuai dengan uji statistik menggunakan Fisher's diperoleh nilai $p$ 0,000 sehingga dikatakan nilai $p<0,05$, maka Ha di terima dan Ho ditolak.

Menurut Sutanto, (2008), tidak semua jenis rematik dipengaruhi oleh faktor makanan. Rematik gout atau asam urat merupakan satu-satunya jenis rematik yang serangannya sangat dipengaruhi oleh pola makan. Mengkonsumsi makanan yang banyak mengandung purin dapat meningkatkan kadar asam urat, yang menyebabkan terjadinya pengkristalisasian dalam sendi. Agar terhindar dari penyakit gout, salah satu caranya menjaga kadar asam urat dalam darah di posisi normal, yaitu 5-7 mg\%. Batasan tertinggi untuk pria adalah 6,5 $\mathrm{mg} \%$ sedangkan untuk wanita 5,5 mg\%. Di atas batas ini, biasanya akan terjadi pengkristalan.

Berdasarkan hasil penelitian, peneliti mendapatkan sebagian responden jenis makanan yang beresiko, dengan responden yang tidak menderita rematik tidak ada, sedangkan yang menderita 58 orang. Hal ini dilihat dari jawaban-jawaban yang telah diisi oleh responden pada saat peneliti membagikan kuesioner tersebut, dimana hampir semua pernyataan tentang jenis makanan yang mengandung purin paling banyak diisi di karenakan mereka sering mengkonsumsi jenis makanan-makanan tersebut.

Namun dari keseluruhan responden terdapat 8 orang yang tidak beresiko serta tidak menderita rematik, dan 3 orang tidak beresiko dari jenis makanan tetapi menderita rematik. Hal ini di akibatkan ada faktor lain yang dapat mempengaruhi sehingga munculnya rematik selain jenis makanan yang mengandung tinggi purin, makanan yang mengandung kolestrol atau lemak juga dapat mempengaruhi timbulnya rematik seperti jeroan (hati, usus, limpa, jantung) karena akan menyebabkan kristalan yang menyebabkan penumpukan pada persendian (Asmi Bramanti, 2012).

Peneliti berasumsi bahwa jenis makanan yang mengandung purin sangat mempengaruhi tubuh seseorang khususnya orang yang sudah lanjut usia dimana daya tahan tubuh dan sistem organ dalam tubuh sudah menurun, jika jenis makanan yang mengandung purin sering dikonsumsi maka akan sangat beresiko munculnya penyakit rematik dan memperparah penyakit tersebut.

\section{KESIMPULAN}

Berdasarkan nilai hasil uji Fisher's diperoleh nilai $p$ : 0,023 yang berarti kurang dari $\alpha$. Dengan demikian dapat dikatakan bahwa ada hubungan yang bermakna antara jenis kelamin dengan penyakit rematik pada lansia di Desa Tial. Jadi Ho ditolak dan H1 diterima.

Berdasarkan nilai hasil uji Fisher's diperoleh nilai $p$ : 0,000 yang berarti kurang dari $\alpha$. Dengan demikian dapat dikatakan bahwa ada hubungan yang bermakna antara pekerjaan dengan penyakit rematik pada lansia di Desa Tial Jadi Ho ditolak dan H1 diterima.

Berdasarkan nilai hasil uji Fisher's diperoleh nilai $p$ : 0,000 yang berarti kurang dari $\alpha$. Dengan demikian dikatakan bahwa ada hubungan yang bermakna antara jenis makanan dengan penyakit rematik pada lansia di Desa Tial Jadi Ho ditolak dan H1 diterima.

\section{DAFTAR PUSTAKA}

1. Dinkes Maluku, (2007). Selayang Pandang Pembangunan Kesehatan Provinsi Maluku. http://profil_maluku_2007.pdf.

2. Departemen kesehatan RI, (2002). Pedoman Praktis Pemantauan Status Gizi Orang Dewasa. Jakarta : Dirjen Bina Gizi Masyarakat.

3. Fajriyah, Nur Afriyanti. (2009). Tingkat Pengetahuan Lansia Tentang Penyakit Rhematoid Arthritis Yang Dipantai Sosial Tresna Werdha Budi Mulia. perpus.fkik.uinjkt.ac.id/file_digital/skripsi.pdf.

4. Hembing, W. (2006). Atasi Rematik dan Asam Urat Ala Hembing. Jakarta: Puspa Swara.

5. Loeckenotte. (1995). Gerontologi Nursing. Mosby : Library Of Congress.

6. Maryam, R. Siti, dkk. (2008). Mengenal usia lanjut dan perawatannya. Jakarta: Salemba Medika.

7. Mansjoer, arif dkk. (2000). Kapita Salekta Kedokteran. Edisi 3. Jakarta : Media Aesculapius

8. Notoatmojo S. (2012). Metodologi Penelitian Kesehatan. Edisi Revisi, Rineka Cipta, Jakarta.

9. Nursalam. (2011). Konsep dan Penerapan Metodologi Penelitian Ilmu Keperawatan. Selemba Medika : Jakarta.

10. Nugroho, W. (2000). Keperawatan Gerontik. Edisi 2. Jakarta. EGC.

11. Resty, Dwi Handayani. (2008). Faktor Resiko Yang Mempengaruhi Terjadinya Osteoarthriris Pada Lansia Di Instalasi Rehabilitasi RSU Haji Surabaya 
http://adln.lib.unair.ac.id/go.php?id=gdlhub-gdlS1-2009handayani-9938.

12. Setiabudhi, T dkk. (2005). Menjaga Keseimbangan Kualitas Hidup Para Lanjut Usia. Jakarta. PT Gramedia Pustaka Utama.

13. Smart. (2010). Rematik Dan Asam Urat Pengobatan Dan Terapi Sampai Sembuh. Yogyakarta : Aplus
14. Smeltzer, C. Suzanne, Bare G. Brenda, (2002). Buku Ajar Keperawatan Medikal Bedah. Jakarta : EGC.

15. Stanley, Mickey. (2006). Buku Ajar Keperawatan Gerontik. Edisi 2. Jakarta : EGC.

16. Sugiyono. (2011). Metode Penelitian Kuantitatif Dan Kualitatif. Alfabeta : Bandung.. 